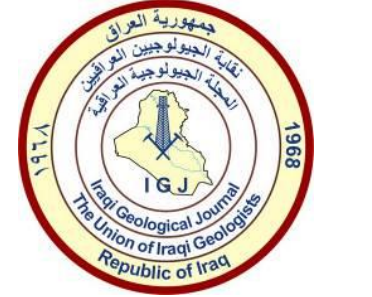

Iraqi Geological Journal

Journal homepage: https://www.igj-iraq.org

\title{
The Cu-Ag-Pb Polymetallic Mineralization of Agdim-Ait Elfersi Sector, North-Eastern Part of the Saghro Massif, Morocco: Geological Setting, Ore Petrography and Geochemistry
}

\author{
Lahcen Ousaid $^{1, *}$, Youssef Hahou ${ }^{1}$, Hassan Admou ${ }^{2}$, El Moustafa Mouguina ${ }^{2}$, Khadija Diani ${ }^{1}$, Rachid \\ Ziadi $^{3}$, Zineb Aafir ${ }^{1}$, Said Courba ${ }^{1}$ and Aziza Lamchaimech ${ }^{1}$ \\ LGEE Laboratory, Department of Earth sciences, Faculty of Sciences, Mohammed V- University Agdal, Rabat, Morocco \\ DLGR Laboratory, Department of Earth sciences, Somalia Faculty of Sciences, Cadi Ayyad University, Marrakech, Morocco \\ Baraka Mining Company, Marrakech. \\ Correspondence: Lahcen ousaid@um5.ac.ma
}

\begin{abstract}
Received: $\quad$ The $\mathrm{Cu}-\mathrm{Ag}-\mathrm{Pb}$ polymetallic mineralization of the Agdim-Ait Elfersi sector is situated in the 5 August 2021 eastern Anti Atlas Moroccan belt, the northeastern part of the Saghro inlier. The mineralization is hosted in the volcanic rocks of late Neoproterozoic and the detrital sedimentary rocks of the

Accepted:

30 October 2021 Lower Cambrian. A network of faults has affected this area; it is a brutalizing deformation with NW-SE, NE-SW, E-W, and NNE-SSW directions. NW-SE and NE-SW structures have a

Published:

31 January 2022 metallogenic significance. This tectonic canvas was used as a target of a mineralization vein with $\mathrm{Cu}, \mathrm{Ag}$, and $\mathrm{Pb}$ in this area. By combining geological, structural, and metallogenic characteristics, it can be assumed that the $\mathrm{Cu}-\mathrm{Ag}-\mathrm{Pb}$ mineralization of the Agdim-Ait Elfersi sector is linked to two major events. A late Pan-African event linked to the extensional tectonics of the late Neoproterozoic, responsible for the establishment of mineralization at the level of the basement, and then a late Hercynian-Atlasic event, which manifests by the remobilization of metals in NE-SW oriented structures. Geochemical analysis shows the polymetallic character of this mineralization. The high contents of silver and mercury observed indicate the presence of similarities of an $\mathrm{Ag}-\mathrm{Hg}$ epithermal type of mineralization in this area. Geological context, as well as mineralogical and textural characters of the Agdim-Ait Elfersi sector are reminiscent of epithermal-type mineralization as in the Imiter and Zgounder deposit.
\end{abstract}

Keywords: Polymetallic mineralization; Agdim-Ait Elfersi; Saghro massif; Ag- $\mathrm{Hg}$ epithermal; Late Neoproterozoic; Lower Cambrian

\section{Introduction}

The Moroccan Anti-Atlas is a vast metallogenic province (Fig. 1-b) that contains numerous deposits and showings of base and precious metals known for more than long years ago. Some deposits are still in operation, and many deposits were abandoned. The Anti-Atlas underwent an extensional tectonic phase at the end of the late Neoproterozoic; it is responsible for the establishment of significant volcanic activity, materialized by the acidic and basic volcanic flows, which form the Ouarzazate group. This magmatic activity has a very interesting effect on the transfer of elements from the mantle to the surface. It could be the source and the convective motor necessary for the formation of a base and a precious metal deposits on the anti-Atlas belt (Cheilletz et al., 2002; Levresse et al., 2004; Gasquet et al.,

DOI: $\underline{10.46717 / \text { igj.55.1A.1Ms-2022-01-20 }}$ 
2005; Marcoux and Wadjinny 2005; Tuduri et al., 2006, 2018; Pelleter et al., 2007; Bouabdellah and Slack, 2016). The previous work and geological studies that had been carried out on this transition zone between the Late Neopoterozoic and the Lower Cambrian in the Saghro inlier, particularly in its northeastern part, are very limited. These studies have emphasized the importance of felsic volcanism generated by this extensional late Neoproterozoic tectonic, in relation to the deposition of the silver mineralization, but they overlook the effect of the Hercynian and Alpine orogeny on the Pan-African structures, knowing that the fault axes that affected the Precambrian basement are continuous in the Paleozoic cover. Indeed, the debate on the saghro ore deposits (Levresse et al., 2004; Tuduri et al., 2006, 2018; Diallo et al., 2021) are for the most part Ediacaran in age and magmatic-hydrothermal related, this discussion meet in a point of the connection and association of magmatic-hydrothermal fluids in the formation of mineralizing events.

The current study aims to characterize the $\mathrm{Cu}-\mathrm{Ag}-\mathrm{Pb}$ polymetallic mineralization of the Agdim Ait Elfersi sector, on one hand, by combining geological setting, ore petrography, and geochemistry data; on the other hand by trying to emphasize the role of the Hercynian and Alpine orogenesis on the establishing of mineralization in the transition zone between late Neoproterozoic and Lower Cambrian, northeast of the Saghro massif. In fact, the Agdim - Ait Elfersi sector is a good example for emphasizing the mineralization of this transition zone. The Agdim-Ait Elfersi sector is located in the Tinghir province, at $25 \mathrm{~km}$ as the crow flies southeast of the city of Tinghir, near the Agdim N Ikhrttan village. This area is located at an average altitude of $1300 \mathrm{~m}$ where there is a semi-desert climate. The access to the area is via a track from the road that leads to Alnif through the rural commune of Ait El-Ferssi and the Agdim N Ikhrttan village.

\section{Geological Settings}

\subsection{Anti-Atlas Belt}

The mountain range of the Moroccan Anti-Atlas, located on the northern edge of the West African Craton (Fig.1-a), belongs to the Pan-African orogenic belt (Choubert, 1963; Leblanc and Lancelot, 1980; Thomas et al., 2002; Ennih and Liégeois, 2008; Hefferan et al., 2014). It stretches $750 \mathrm{~km}$ in a WSW-ENE direction, from the Atlantic, where it extends the Zemmour range to Tafilalet. It is the major structural domain of southern Morocco, limited to the south by the Carboniferous basin of Tindouf and by a major tectonic lineament called the major South Atlas Accident in the North (fig.1-b) (Choubert, 1963; Thomas et al., 2004; Gasquet et al., 2005, 2008). The Anti-Atlas is constituted by a Precambrian basement, exposed in the form of inlier (Bas Draâ, Ifni, Kerdous, Tagragra of Akka, Tagragra of Tata, Igherm, Sirwa, Zenaga, Bou Azzer, Saghro, and Ougnat) under a Paleozoic and post-Paleozoic cover (Fig.1-b). The oldest formations have been recognized in the south of the Major Anti-Atlas Fault (Choubert, 1963; Bouougri, 2003; D’Lemos, Inglis, and Samson 2006; Gasquet et al., 2005, 2008), include meta-sedimentary and meta-volcanic complexes intersected by Paleoproterozoic plutonic intrusions (Gasquet et al., 2008). Recently, Mesoproterozoic rocks are recognized by basic dykes dated by U-Pb on baddeleyite at 1385-1415 Ma (El Bahat et al., 2017) and sediments from the Taghdout-Lkest Group, whose zircon dates have revealed ages of 1416-1380, 1650, 1750, and 2040 Ma (Youbi et al., 2013) and $1700 \mathrm{Ma}$ (Ikenne et al., 2017).

The Neoproterozoic of the Anti-Atlas was subdivided into several groups, the oldest of which form Cryogenian units. These are the Lkst-Taghdout and Tachdamt-Bleida groups (1000-690 Ma), Iriri group (760-740 Ma), Bou Azzer group (762-697 Ma), and Saghro group (760-610 Ma). The Anzi, Bou Salda, Dades and Tiddiline groups form the Ediacaran units; Ouarzazate group (580-540 Ma) covers these units (Álvaro et al., 2014; Gasquet et al., 2008; Hefferan et al., 2014; Karaoui et al., 2015; Soulaimani et al., 2018). The margin of the West African Craton (WAC) is experiencing a major transgression towards the southeast at the Paleozoic. The first deposits are detrital, followed by Cambrian platform 
sedimentation. It was during this period that Tata and Taroudant groups were deposited (Choubert, 1963; Destombes et al., 1985; Álvaro et al., 2014; Landing et al., 2006). They are constituted of limestone and dolomite, separated by Taliwine formation marking a brief episode of regression. The Precambrian-Cambrian boundary in the Anti-Atlas is placed under the contact between the lower dolomite and the Taliwine formation dated Tommotian (Sdzuy, 1978; Tucker 1986; Latham and Riding, 1990). Geochronological dating by U-Pb on zircon places this boundary beside the lowest carbonate unit of Addoudou formation, under the Tata group (Maloof et al., 2005; Landing et al., 2006; Letsch et al., 2019).

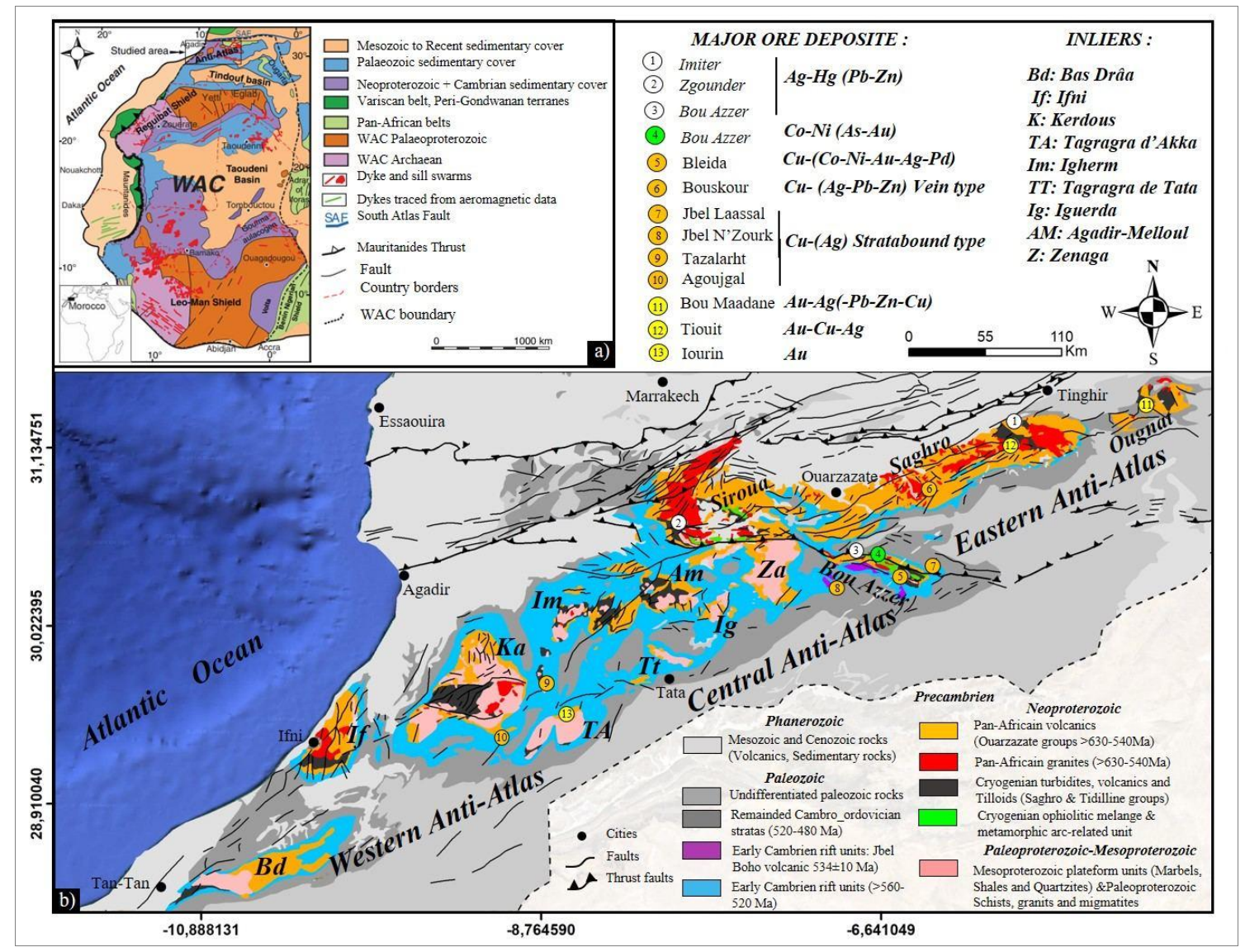

Fig. 1. (a) Location of the Anti-Atlas belt at the northern limit of the West African Craton (Fabre 2005; Liégeois et al., 2005; Ennih and Liégeois, 2008); (b) Main geological units and major mining districts of the Moroccan Anti-Atlas (Hollard et al., 1985; Thomas et al., 2004; Mouttaqi et al., 2011; Tuduri et al., 2018)

\subsection{Saghro Massif}

The Saghro massif is located in the west of the eastern Anti-Atlas. It is formed by the oldest formations outcrop in four sectors that will also be defined as smaller inlier, surrounded by thick late Precambrian and Adoudounian formations. These sectors are Sidi Flah - Bou Skour and Kelaa M'gouna inlier in the western part; Boumalne and Imiter inlier in the eastern part (Hindermeyer et al., 1974). Siliciclastic and metasedimentary rocks compose the saghro group in the eastern anti atlas Moroccan belt, a Cryogenic age has been attributed to these rocks (Ouguir et al., 1996; Fekkak et al., 2003; Thomas et al., 2004). Even so, it was considered as an Ediacaran in age (Liégeois et al., 2006; Abati et al., 2010) based on the geochronological dating by the U-Pb method and their stratigraphic position in the central anti atlas. The vocano-sedimentary cover of the Ouarzazate group, whose type features have been defined in the Ouarzazate region (Hindermeyer 1953; Boyer and Leblanc, 1977; Boyer et al., 1978) is 
covered the saghro group. This volcano-sedimentary cover is characterized by a calco-alkaline strongly potassium to shoshonitic magmatism of volcanic arc type (Gasquet et al., 2005; Walsh et al., 2012; Baidada et al., 2018; Yajioui et al., 2020), associated with plutonic intrusions attributed to 590-540 Ma (De Wall et al., 2001; Gasquet et al., 2005; Walsh et al., 2012; Baidada et al., 2018; Errami et al., 2020).

\subsection{Agdim Ait Elfersi Sector}

The Agdim-Ait Elfersi sector is located at the eastern of the Jbel saghro massif, in the Neoproterozoic - Paleozoic transition zone. The Paleozoic sedimentary series outcrops in the north of the study area rest in the major type of angular unconformity on the volcanic and volcano-clastic rocks of the Ouarzazate group (Dal Piaz et al., 2007; Malusà et al., 2007). The Neoproterozoic rocks is formed by volcanic and pyroclastic rocks (Dal Piaz et al., 2007; Malusà et al., 2007). They are represented by two complexes, an andesitic-rhyolitic complex of Ijgui-Jbel Merrou, and a pyroclastic complex of Thiboula-Bou Afzdad (Dal Piaz et al., 2007). The Paleozoic rocks are represented by the Lower and Middle Cambrian and the Ordovician features with a stratigraphic gap during the Upper Cambrian (Hindermeyer et al., 1974; Du Dresnay et al., 1988; Malusà et al., 2007).

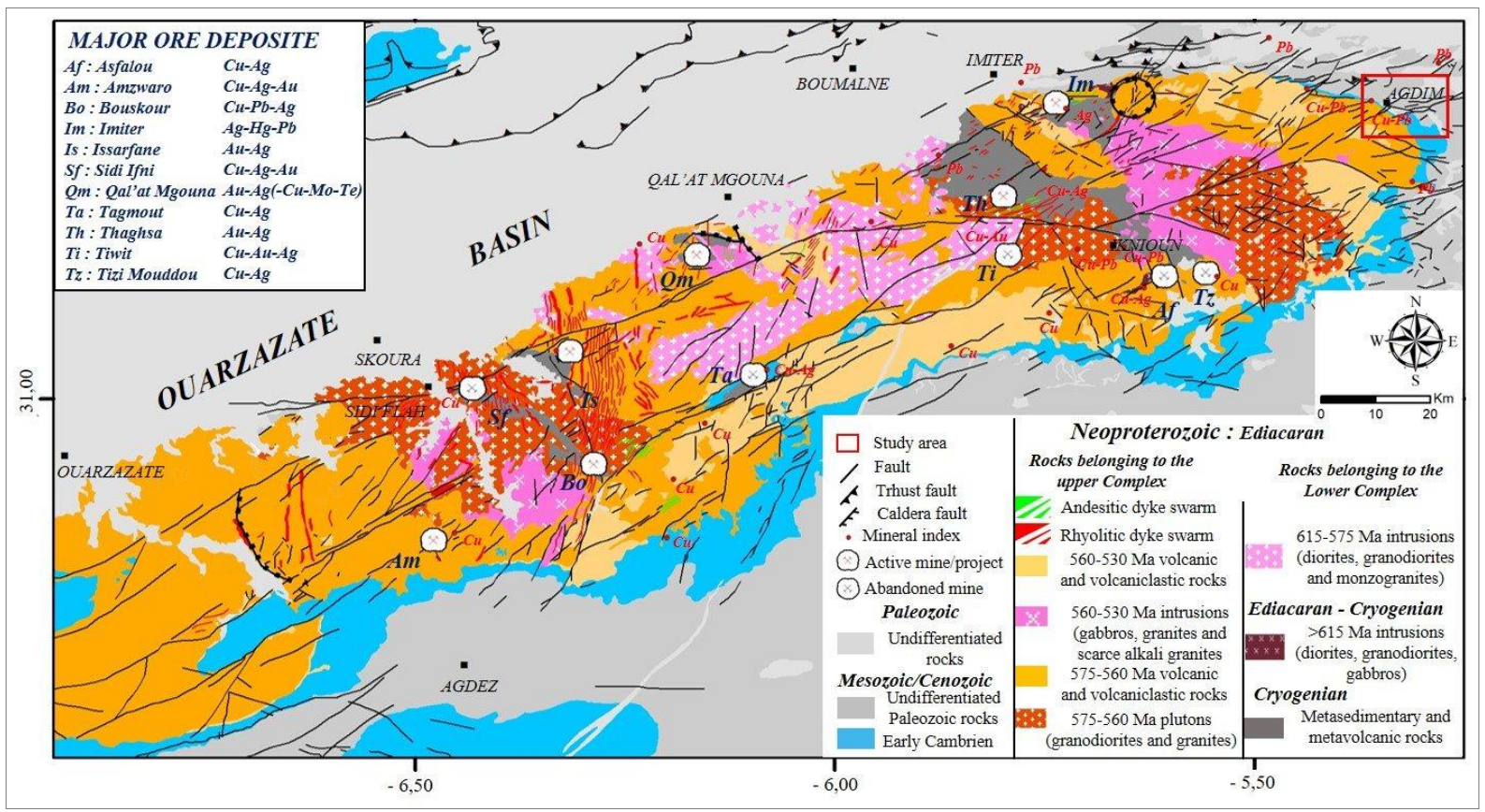

Fig. 2. Geological map of the Jbel Saghro inlier (Hindermeyer 1953; Hindermeyer et al., 1974; Tuduri et al., 2018)

\section{Materials and Methods}

The volcanic rocks of the Precambrian basement and the detrital rocks of the Lower Cambrian host the Agdim-Ait Elfersi mineralization. With the aims of characterizing, the $\mathrm{Cu}-\mathrm{Ag}-\mathrm{Pb}$ veins mineralization's of this sector, geological and mineralized-structures maps have been produced. Field mapping are carried out in three phases, which have a progressive relationship, detailed planning, description/collecting, and reporting/interpretation. Geological study summarizes the different features and structures defined in the field. Geological sections had been chosen to intersect perpendicularly the contact of the transition zone between the late Neoproterozoic and Lower Cambrian and the various mineralized structures. About 60 samples were collected from the surface for petrographic, mineralogical, and geochemical characterization. Thin and polished sections were prepared at the Faculty of Science of Marrakesh. They are microscopically investigated using crossed polarized light 
(XPL), plane polarized light (PPL), reflected light photomicrographs and scanning electron microscopy (SEM). The geochemical analyses were carried out by the Baraka Mining Company at the ALS laboratory in Spain. Geochemical samples are analyzed for 17 elements ( $\mathrm{Au}, \mathrm{Ag}, \mathrm{Hg}, \mathrm{As}, \mathrm{Bi}, \mathrm{Cd}, \mathrm{Co}, \mathrm{Cr}$, $\mathrm{Cu}, \mathrm{Fe}, \mathrm{Mg}, \mathrm{Mn}, \mathrm{Mo}, \mathrm{Ni}, \mathrm{Pb}, \mathrm{S}$ and $\mathrm{Zn}$ ) using inductively coupled plasma atomic emission spectroscopy (ICP-AES) and atomic absorption spectroscopy (AAS) method.

\section{Results}

\subsection{Geological and Structural Study}

The Agdim-Ait Elfersi sector, formed by two large composite of rocks (Fig.3), a volcanic and pyroclastic rocks of the terminal Neoproterozoic, surmounted by detrital sedimentary rocks of the Paleozoic cover (Dal Piaz et al., 2007; Malusà et al., 2007). The terminal Neoproterozoic is represented by volcano-sedimentary rocks, called the Ouarzazate group. Indeed, these rocks are neither folded nor metamorphosed on a regional scale. This complex comprises a panoply of volcanic and pyroclastic rocks outcropping to the south of the study area (Fig.3). It constituted by a stack of terms and features, from basic to intermediate features, corresponding to porphyritic andesite, to more acidic terms, corresponding to pink rhyolites generated by the transtensional tectonic event of the Anti-Atlas Moroccan belt during the transition phase between the terminal Neoproterozoic and the Lower Cambrian. Without forgetting the ignimbrites and volcanic tufts which come from the pyroclastic projections and the chaotic breccias which corresponds to the detrital sedimentary features. These sets of rocks were cut by a set of doleritic, andesitic and rhyolitic dykes.

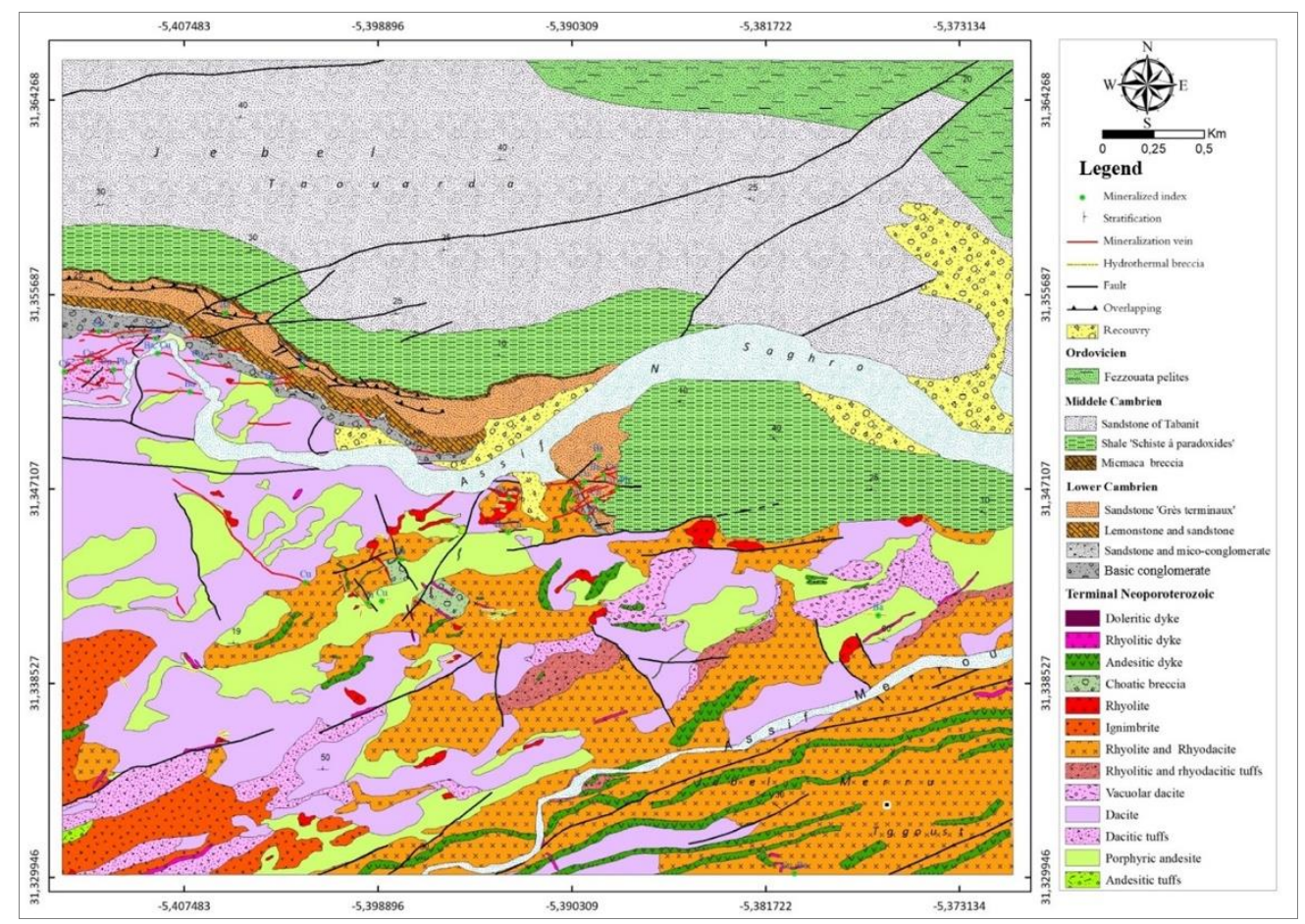

Fig. 3. Geological map of Agdim-Ait Elfersi sector. These formations were affected by very important brittle tectonics (Fig.3 and Fig.4 h).

The Paleozoic cover is characterized by a series of lateral detrital and carbonate features attributed to Lower and Middle Cambrian (Fig.3), with rare calcareous intercalations attached to the Tata Group. The basic conglomerates rest in angular unconformity on the Neoproterozoic formations. These 
conglomerates contain pebbles and subangular elements with variable sorting. Their composition is polygenic and dominated by volcanic and pyroclastic rocks elements. An association of clay and carbonate mixed platform of the Amousslek-Issafene formation marks the passage to the sandstones of Asrir formations (Fig.3). This formation caps the summit of the Lower Cambrian corresponds to a rose sandstone bar composed of a monotouns stack of multidicemeter lenticular layers of fine-grained sandstones. The middle Cambrian begins with Micmaca barcia invaded by green pelites of Jbel Wawrmast formations and the sandstone of Tabanite group (Fig.3). The remainder of the Paleozoic series are the Ordovician deposits of the external Feijas group with a stratigraphic gap during the Upper Cambrian.

The relationships between the different structures raised in the field allow us to identify and distinguished three main fault systems. This is a brittle deformation defined as follows:

- NE-SW System

This system brings together faults from various directions between $\mathrm{N} 45^{\circ}$ and $\mathrm{N} 65^{\circ}$ (Fig.4 a-b-c-e and $\mathrm{h}$ ); it is well exposed in the field and constitutes the most abundant and important family in our study area. This network of faults affects both the Precambrian basement and Paleozoic cover. These structures have a strong dip, predominantly south-easterly, and present a dominant dextral movement rather than a sinister one; less described. The NE-SW system intersects the entire structures oriented $\mathrm{N} 110^{\circ}$ to $\mathrm{N} 140^{\circ}$ and that of $\mathrm{N} 80^{\circ}$ to $\mathrm{N} 100^{\circ}$.
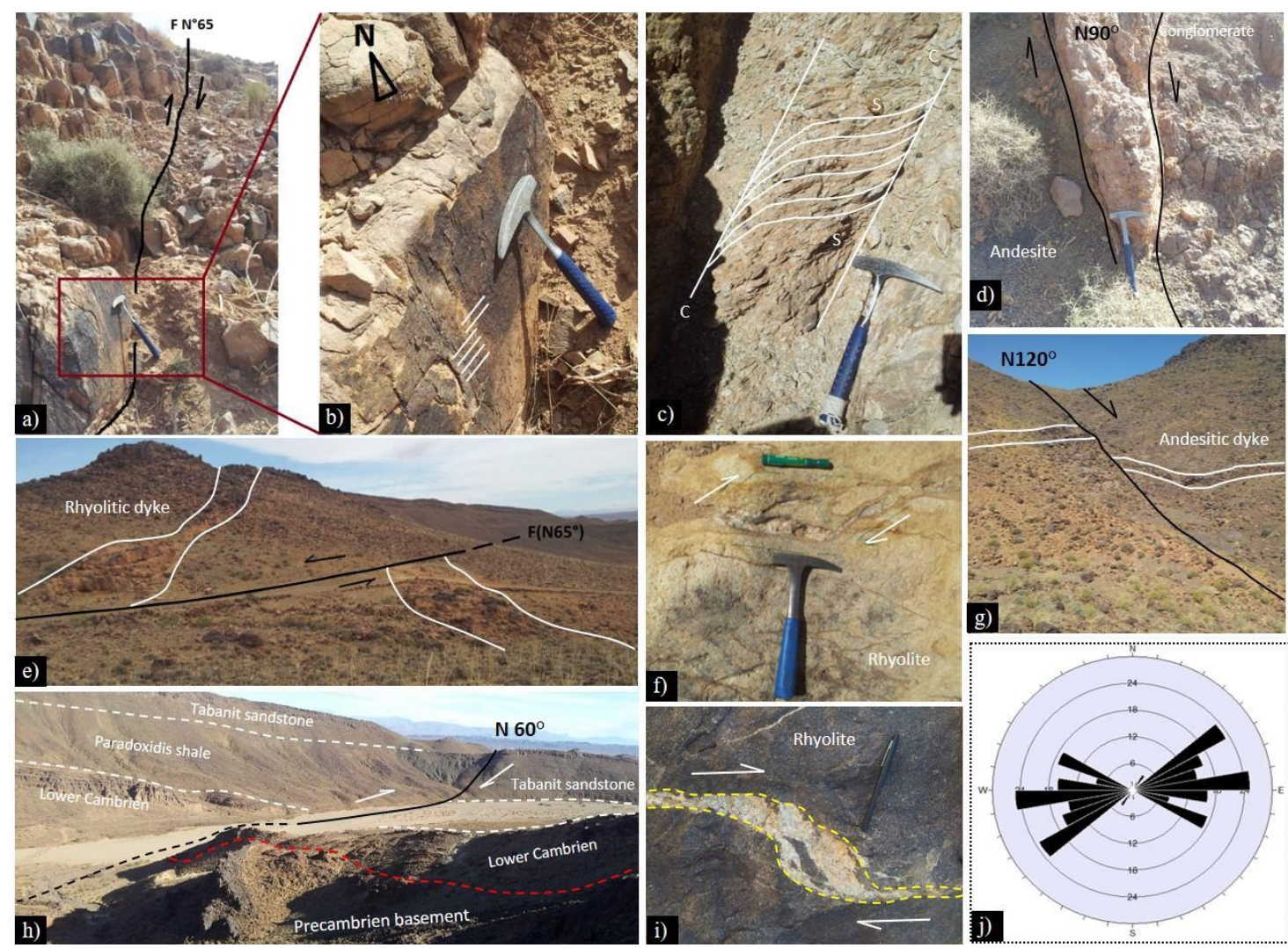

Fig. 4 . Photograph showing a brittle deformation defined in the study area: a-b-c-e and h) NE-SW fault system with striation in (b); S-C shears fabrics in (c); dextral and sinistral kinematics in (e) and (h); d) E-W fault system; f-g and i) NW-SE fault system with a dextral kinematics in (f-i); and j) Rosette diagram for faults of the Agdim Ait-Elfersi sector 
- $\quad$ E-W system

It is represented by the structures essentially oriented N80 to N100 with a subvertical dip (Fig.4 d). It is an abundant family and develops mainly at the transition zone between the Neoproterozoic and the Lower Cambrian. These structures show in their kinematics sinistral strike-slip movement and sometimes a dextral strike-slip movement. The sinistral clearance appears to be more abundant.

- NW-SE system

It has dextral kinematics and brings together all the structures which have a varied direction between N110 to N140 (Fig. 4 g) with an essentially subvertical dip, sometimes reaching $65^{\circ}$ towards the northeast. This family mainly affects the Precambrian basement with a decametric to kilometer extension. These structures are less expressed and intersected by other fault systems detected in the field. On the surface, these structures have a pull-apart opening confirming dextral kinematics (Fig. $4 \mathrm{f}$ and i). The structural synthesis of the Agdim - Ait Elfersi sector indicates the presence of breaking and strike-slip tectonics associated with a shear zone with the development of the C/ S fabrics (Fig.4 c). This shear zone is linked to an intersection between two complex systems of faults (Fig.7); E-W fault in the north with a dextral movement and NE-SW fault with a sinister movement in the south (Fig.7).

\subsection{Petrography and Hydrothermal Alterations}

\subsubsection{Basic to intermediate rocks}

The basic to intermediate corteges are andesitic rocks. These basic to intermediate rocks of the late Neoproterozoic series of the studied sector present two types of deposits, either andesitic lava flows or intrusive dykes in the volcanic series. All of these rocks are dark, grey in color, sometimes brown to greenish.

- Brown to greenish porphyritic andesites (Fig. 5 a and a'): Macroscopically, they are brown to greenish porphyritic rocks with small tablets of feldspar. In the thin section, they have a porphyritic microlithic texture with the development of a primary paragenesis formed by plagioclase, pyroxene, and opaque minerals. The plagioclase phenocrysts, very abundant, vary in size from 1 to $5 \mathrm{~mm}$. They are polysynthetic twins and altered to sericite and calcite. Pyroxene appears in phenocrysts can reach $1 \mathrm{~mm}$ and is transformed slightly into amphibole and chlorite.

- Dark gray porphyritic andesite (Fig. 5 b and b'): Macroscopically, they are porphyritic rocks of a dark grey color with small tablets of feldspar. In thin section, they have a more or less brecciated porphyritic microlithic texture, formed of very abundant plagioclase, calcite, chlorite and opaque minerals more abundant than in brown to greenish porphyry andesite. The plagioclase phenocrysts vary in size from 0.5 to $2 \mathrm{~mm}$; they are polysynthetic twinning and deteriorate into sericite and calcite. Their breccia appearance can be explained by a brittle deformation linked to a late hydraulic pressure.

\subsubsection{Acid rocks}

The felsic rocks of the series studied consist of rhyolitic, rhyodacite, dacitic, and pyroclastic rocks. They present two types of deposits, either in the form of acidic volcanic flows or in the form of intrusive dykes in the volcanoclastic series.

- Dacites (Fig. 5 c, c', d and d'): They are reddish to purplish colored rocks. In thin section, they have a brecciated aspect (Catalasite) and showing a primary paragenesis formed by quartz, plagioclase, biotite, and opaque minerals. Secondary paragenesis is expressed by sericite, chlorite and iron oxides. Quartz scarce compared to plagioclase. It is xenomorphic up to $0.5 \mathrm{~mm}$ in size. We also note the appearance of a secondary quartz linked to the phenomenon of recrystallization, either in late fractures or at the edges of primary quartz. Plagioclases are twinned polysynthetic and have 
a millimeter size; they are automorphic to subautomorphic and partially altered to sericite. Biotite is very rare and altered to chlorite. It appears in elongated crystals sometimes in rods of brown tint. Opaque minerals are also observed in this rock; they have an inframilimetric size.

- Rhyodacites (Fig. 5 e and e'): In the thin section, they present a primary paragenesis formed by quartz, plagioclase, biotite, and opaque minerals. Secondary paragenesis is expressed by chlorite, sericite, and iron oxides. Compared to dacites, they differ only in the proportions of the primary mineral phases expressed as phenocrysts. They were marked by an increase in quartz percentage. Rhyodacites distinguished from rhyolites by the absence of potassium feldspar in their phenocrystalline phase.

- Pink rhyolites (Fig. 5 f and f'): They are pink to whitish colored rocks. In thin section, they have a fibrous appearance and show a primary paragenesis formed by quartz, plagioclase, potassium feldspar (microcline), and opaque minerals, while secondary paragenesis is expressed by sericite. According to microscopic observation, chlorite and iron oxides are associated with a late event as they crystallize in cracks and pull-apart structures observed in this rock.

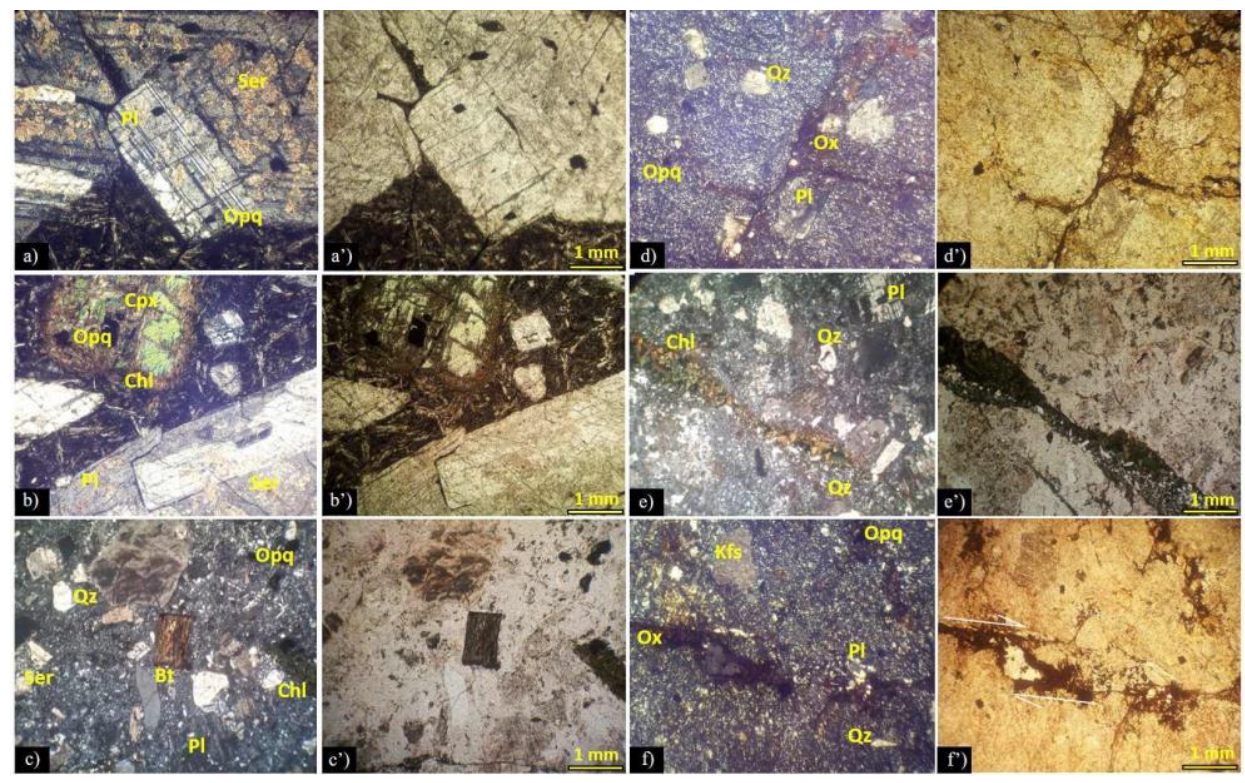

Fig. 5. Photomicrograph of thins sections of the volcanic rocks of the study area: Brown to greenish porphyritic andesites (a-PPL and a'-XPL); Dark gray porphyritic andesites (b-PPL and b'-XPL); Dacites rocks (c and d-PPL, c' and d'-XPL); Rhyodacites rocks (e-PPL and e'-XPL) and pink rhyolites (f-PPL and $\left.f^{\prime}-X P L\right)$

\subsection{Hydrothermal Alterations}

Hydrothermal alterations are expressed in the form of hydrothermal circulations around and in the various features, of the Neoproterozoic basement and of the Paleozoic cover. Hydraulic breccia (Fig.6 e and f), altered corridors and oxidation zones have an orientation coinciding with the main directions of the mineralized veins. The most discreet manifestations of this circulation of the fluid are marked by the presence of carbonate veins (Fig.6 c) sometimes associated with quartz and iron oxides, filling fractures mainly in andesites, rhyodacites and pink rhyolites. The most dominant hydrothermal alterations in Agdim-Ait Elfersi sector correspond in particular to:

\section{- Silicification}

It is highlighted by the abundance of lenticular of silica (Fig.6 b), veinlets and veins of quartz in the different features of the studied sector. Almost all the thin sections studied show the presence of two generations of quartz. The first generation is in the form of a filling of the fractures and late 
microfractures that affected the volcanic features. The second is occurring in cracks and mineralized veins in the form of saccharoid quartz and hilly quartz.

\section{- Hematitization}

It affects the majority of features in the study area (Fig.6 a). This phenomenon is well developed around veins, cracks and iron caps carrying mineralization. At the level of thin sections, the development of iron oxides in all the features studied is the main cause of this alteration (Fig.5 d and f).

\section{- Chloritization}

Macroscopically, chloritization affects the majority of features in the area studied. It is clearly visible in the form of millimeter veinlets, especially in rhyolites (Fig.6 d), grey to greenish rhyodacites and also in the form of cement in hydraulic breccias. On the microscopic scale, chloritization marked by the presence of replacement texture chlorite around the ferromagnesian minerals, it is an outcome of a chlorite hydrothermal circulation (Fig.5 e).

\section{- Carbonatation}

It is very abundant in the study area, on a macroscopic scale, it consists in the replacement of fractures and veins by calcite and ankeritis (Fig.6 c). In thin sections, it is marked either by the presence of calcite minerals resulting from the alteration of plagioclase feldspar (especially in andesitic features), or by the replacement of microfractures by carbonates.

\section{- Sericitization}

In thin sections (Fig.5), it is marked by the presence of sericite in the secondary mineralogical parageneses of the rocks studied, especially in the andesitic and rhyolitic features. This type of alteration results from the transformation of plagioclases into sericite.
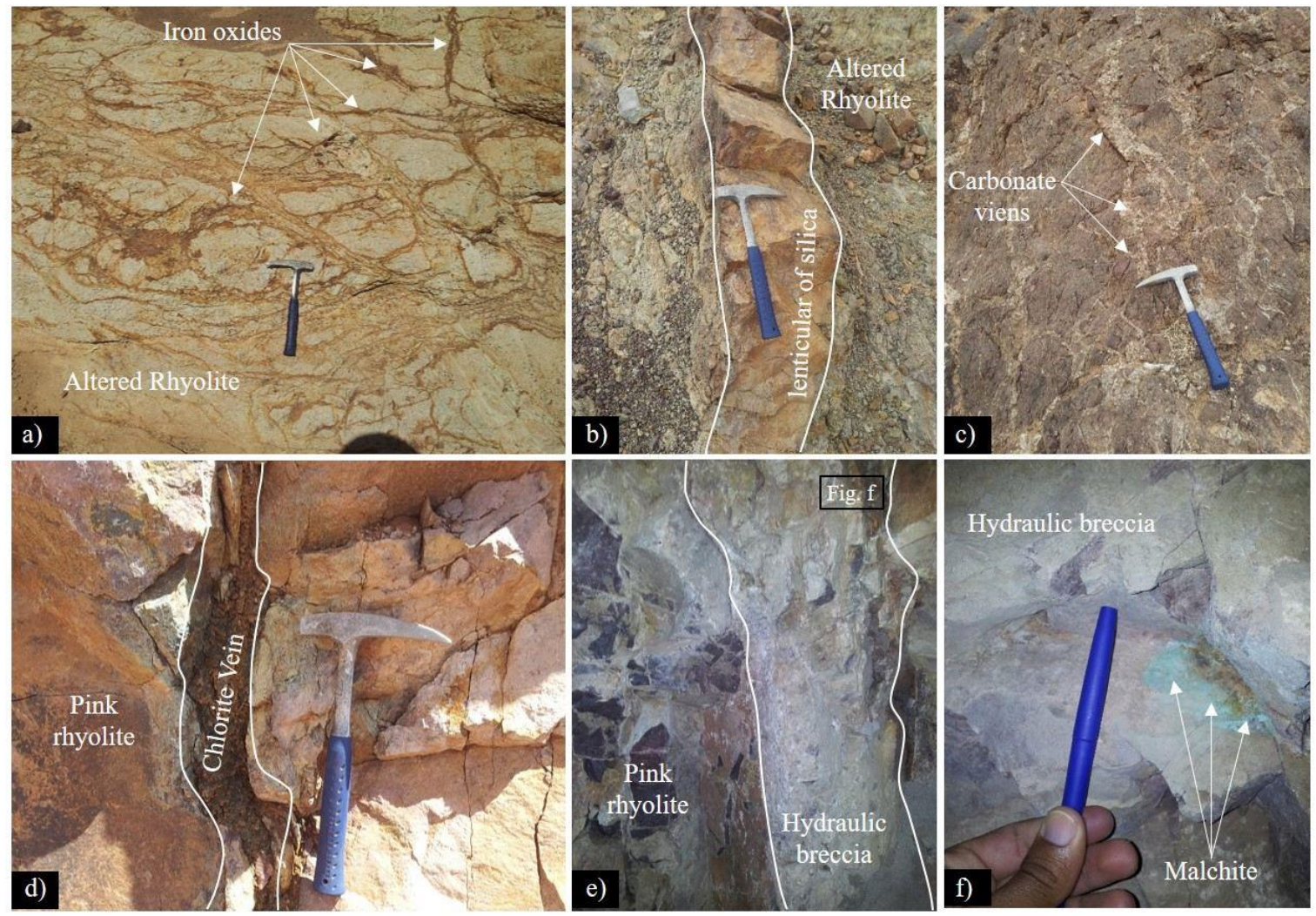

Fig. 6. Hydrothermal alteration from the Agdim -Ait Elfersi sector: a) iron oxides vein in the rhyolite rocks; b) lenticular silica in altered rhyolite; c) carbonate veins; d) Chlorite vein in the pink rhyolite; $d$ and f) mineralized hydraulic breccia in the pink rhyolite 
The terminal Neoproterozoic magmatic rocks of the studied area show the presence of two components, on the one hand, a basic to intermediate cortege made up of flows and dykes of porphyritic andesites, on the other hand, an important acidic cortege of rhyolitic and pyroclastic rocks. These rocks exhibit a significant degree of hydrothermal alteration, during which the primary minerals have been partially or completely transformed into secondary products. We thus distinguish silicification, sericitization, haematitization, chloritization, and carbonation as types of hydrothermal alterations.

The expression of hydrothermal circulations is in the form of altered corridors, zones of oxidation and hydraulic breaches. Their orientation coincides with the main directions of potential structures in mineralization. The greatest concentrations of these hydrothermal expressions were observed in the rhyolitic features. Their cement (Fig.6 $\mathrm{f}$ and Fig. $8 \mathrm{f}$ ) consists of chlorite, quartz, iron oxides, malachite and sometimes chalcopyrite. Consequently, the rhyolite could constitute the source and the convective motor of hydrothermal circulations responsible for deposits and the genesis of polymetallic mineralization of the Agdim - Ait Elfersi sector.

\subsection{Mineralization}

The studied sector presents disseminated and vein type mineralization. It is disseminated in the rhyolitic features of the felsic volcanism of the Ouarzazate group (Fig.8 d and Fig.9 a), and in the following vein form of the mineralized structures hosted in the formations of Neoproterozoic basement and their Paleozoic cover, specifically in the detrital features of the Lower Cambrian (Fig.7). These structures are veins, faults, and recesses filled by hydrothermal circulations with intense breccia and oxidation (Fig.7 e) that varies from one zone to another depending on the nature of the filling and the lithology hosted. The potential mineralized structures of Agdim Ait Elfersi have NW-SE, E-W, and NE-SW principal directions, with a length of 200-300 $\mathrm{m}$ and 20-50 $\mathrm{cm}$ in thickness.

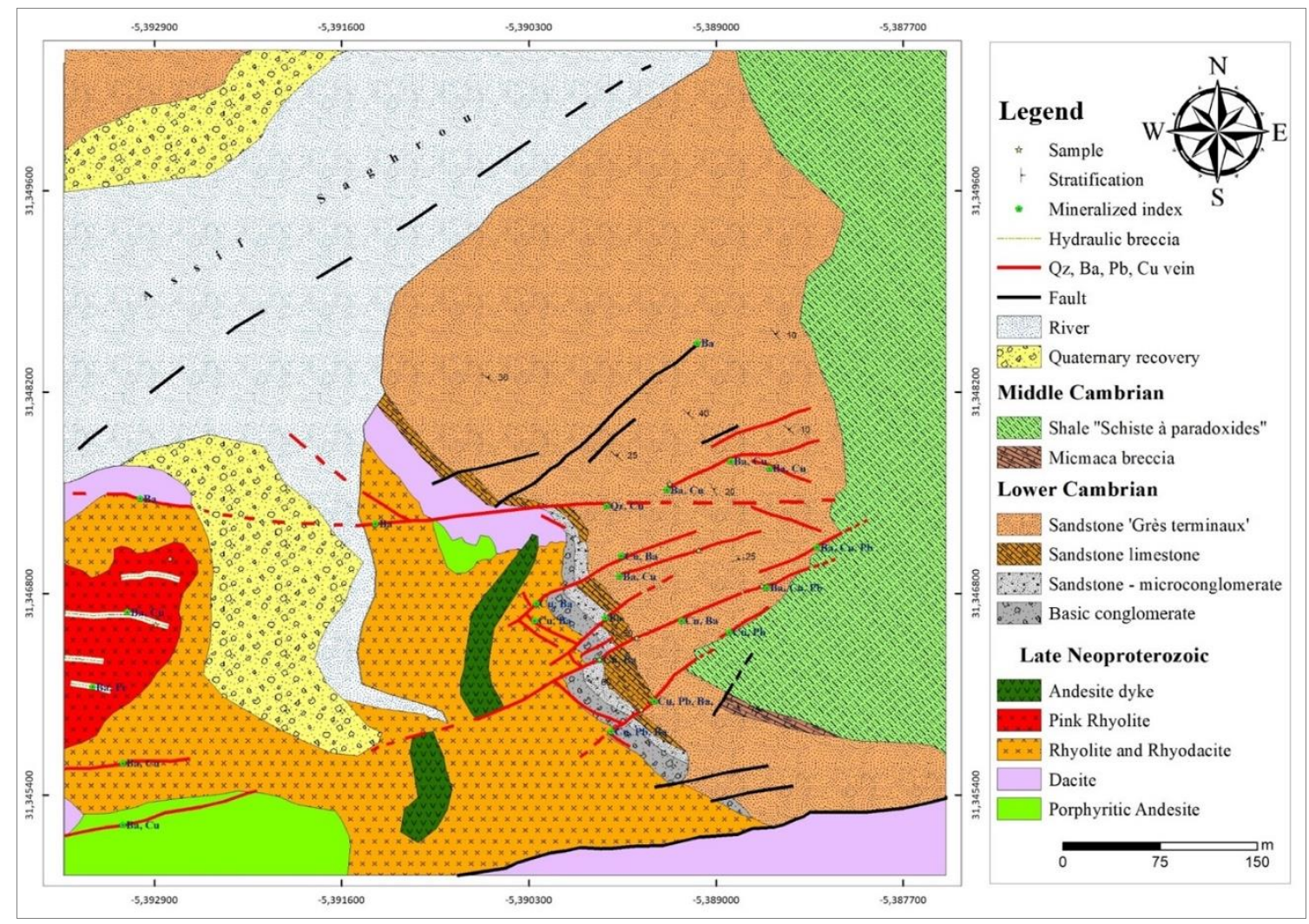

Fig. 7. Mineralization-structures map of the study area 
The ore mineralogy of Agdim - Ait Elfersi sector are represented by sulfides were introduced during different hydrothermal episodes as indicated by the development of hydrothermal breccias and the presence of sulphide minerals (Fig. $8 \mathrm{f}$ ) in the hydrothermal weathering minerals. Field observations of the mineralized structures (Fig.8 a, b and c) and the reflected light microscopy (Fig.9) combined with scanning electron microscopy Fig. 10 have revealed the presence of a very diverse range of minerals. All ores minerals are fine grained and accompanied by gangue minerals, such quartz, barite and chlorite. Minerals identified in the Agdim - Ait Elfersi sector by optical microscopy include chalcopyrite, chalcocite, galena, sphalerite, pyrite, cerussite, covellite, deginite, malachite and azurite. Gold and silver are not observed microscopically in the studied samples, they were detected by geochemical analyzes. SEM analyzes revealed the presence of silver in the chemical composition of chalcocite, chalcopyrite and pyrite (Fig.10 a and b).

\section{- Pyrite $\left(\mathrm{FeS}_{2}\right)$}

Pyrite is the most abundant mineral in the studied area; it crystallizes in the form of a classical cubic habitus (Fig.9 a), large in size, generally of the order of a centimeter, scattered in pink rhyolites and andesite dykes of the volcanic series. In mineralized structures, it is xenomorphic and associated with chalcocite and chalcopyrite. Pyrite crystals are fully or partially pseudomorphs to iron oxides.

\section{- Chalcopyrite $\left(\mathrm{CuFeS}_{2}\right)$}

Chalcopyrite is associated with pyrite and chalcocite. It exists in small xenomorphic crystals disseminated (Fig.9 $\mathrm{c}$ and $\mathrm{d}$ ) in the quartz and barite matrix of the various mineralized structures observed at the scale of the area studied. Chalcopyrite is partially or totally replaced by malachite and / or azurite.

\section{- Chalcocite $\left(\mathrm{Cu}_{2} \mathrm{~S}\right)$}

The chalcocite is a mineral species composed of copper sulphide (Fig.9 g) with the chemical formula $\mathrm{Cu}_{2} \mathrm{~S}$. Semi-quantitative Scanning Electron Microscope analyzes indicate that chalcocite contained traces of Ag, Fe, Mn, Co, Ni (Fig.10 b).

\section{- Galena $(\mathbf{P b S})$}

Galena is very abundant, especially in the structures-oriented NE-SW, and occurs in the form of crystals disseminated in the quartz matrix (Fig.9 b). Crystals are fully or partially pseudomorphs to cerussite.

\section{- Sphalerite (ZnS)}

Sphalerite is very small and occurs as inclusions in chalcopyrite (Fig.9 e). It is in traces associated with chalcopyrite and these minerals alteration.

\section{- Cerussite $\left(\mathrm{PbCO}_{3}\right)$}

Cerussite is a secondary alteration mineral of galena with the chemical formula $\mathrm{PbCO} 3$. It comes in the form of a replacement texture in the borders of the galena. The microfractures that have affected galena are clogged by cerussite (Fig.9 b).

\section{- Covellite $(\mathrm{CuS})$ and digenite $\left(\mathrm{Cu}_{9} \mathrm{~S}_{5}\right)$}

Covellite and digenite are alteration minerals that appearing in the secondary phase.They are linked to the destabilization and alteration of chalcopyrite (Fig.9 f). 


\section{- Malachite $\mathrm{Cu}_{2}\left(\mathrm{CO}_{3}\right)(\mathrm{OH})_{2}$ and Azurite $\mathrm{Cu}_{3}\left(\mathrm{CO}_{3}\right)_{2}(\mathrm{OH})_{2}$}

Copper carbonates are secondary oxidation minerals that indicate the presence of a cementation zone linked to a supergene alteration episode.

\section{- Iron oxides}

Iron oxides (Goethite, etc.) are very abundant throughout the area studied. They borrow the same forms from ancient pseudomorphs pyrite. These oxides are evidence of strong oxidation linked to a late hydrothermal event.

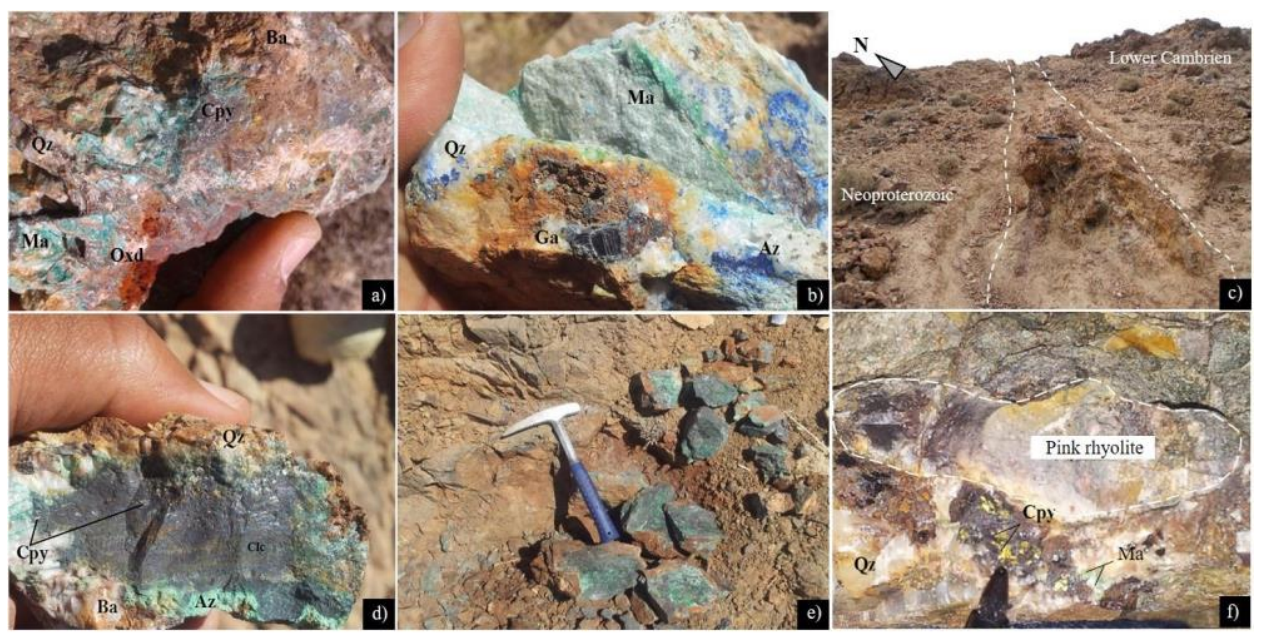

Fig. 8. Photograph showing minerals from the mineralized structures of the Agdim - Ait Elfersi sector: a) Malachite, barite and iron oxides; b) Malachite, azurite and galena in a quartz matrix; c) Gossanous Polymetallic vein; d) Quartz, barite, chalcocite, malachite, chalcopyrite and oxides; e) malachite and azurite disseminated in rhyolitic rocks and f) Chalcopyrite, malachite and oxides in a hydraulic breccia
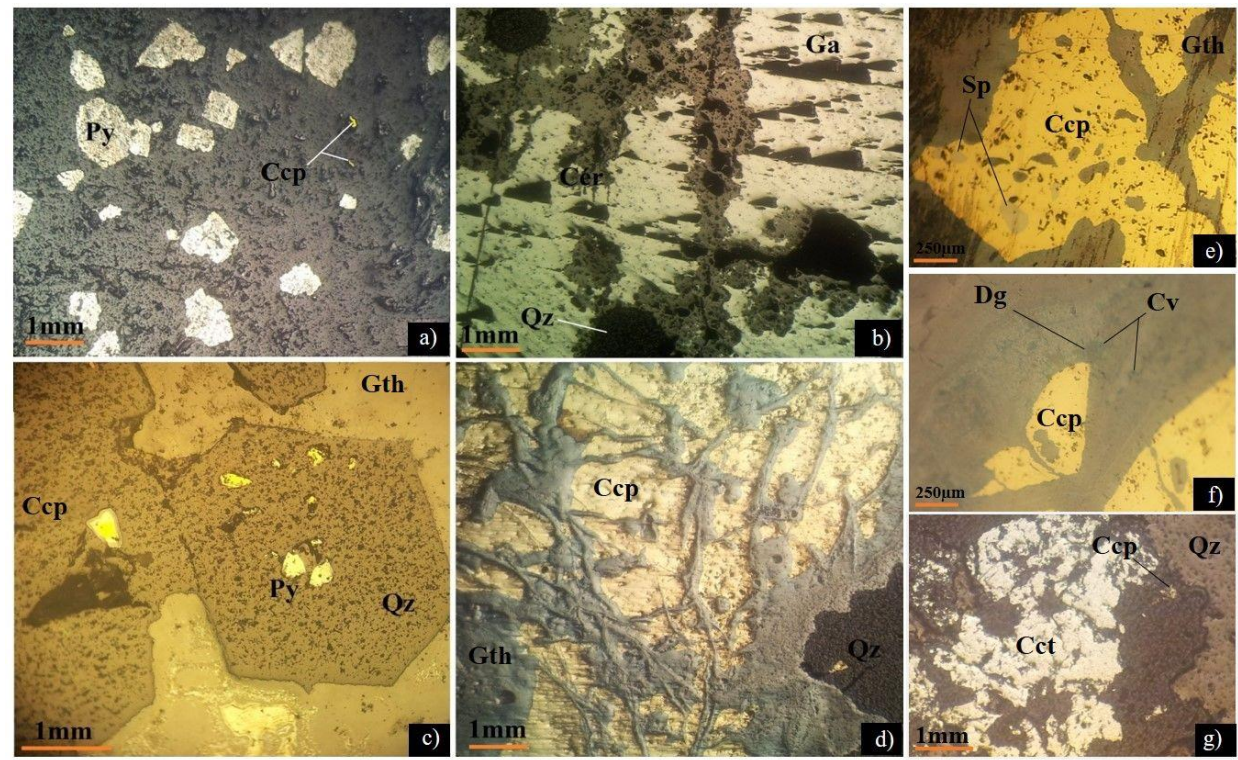

Fig. 9. Reflect light photomicrographs of polished sections from the studied area: a) pyrite and chalcopyrite disseminated in rhyolites; b) Galena showing triangle pits and replaced by cerussite; c) Inclusions of pyrite and chalcopyrite in a hexagonal section of quartz; $d$ and f) Replacement of chalcopyrite in covellite, deginite and goethite; e) Inclusion of sphalerite in chalcopyrite and g) Chalcocite and chalcopyrite crystals in quartz matrix 


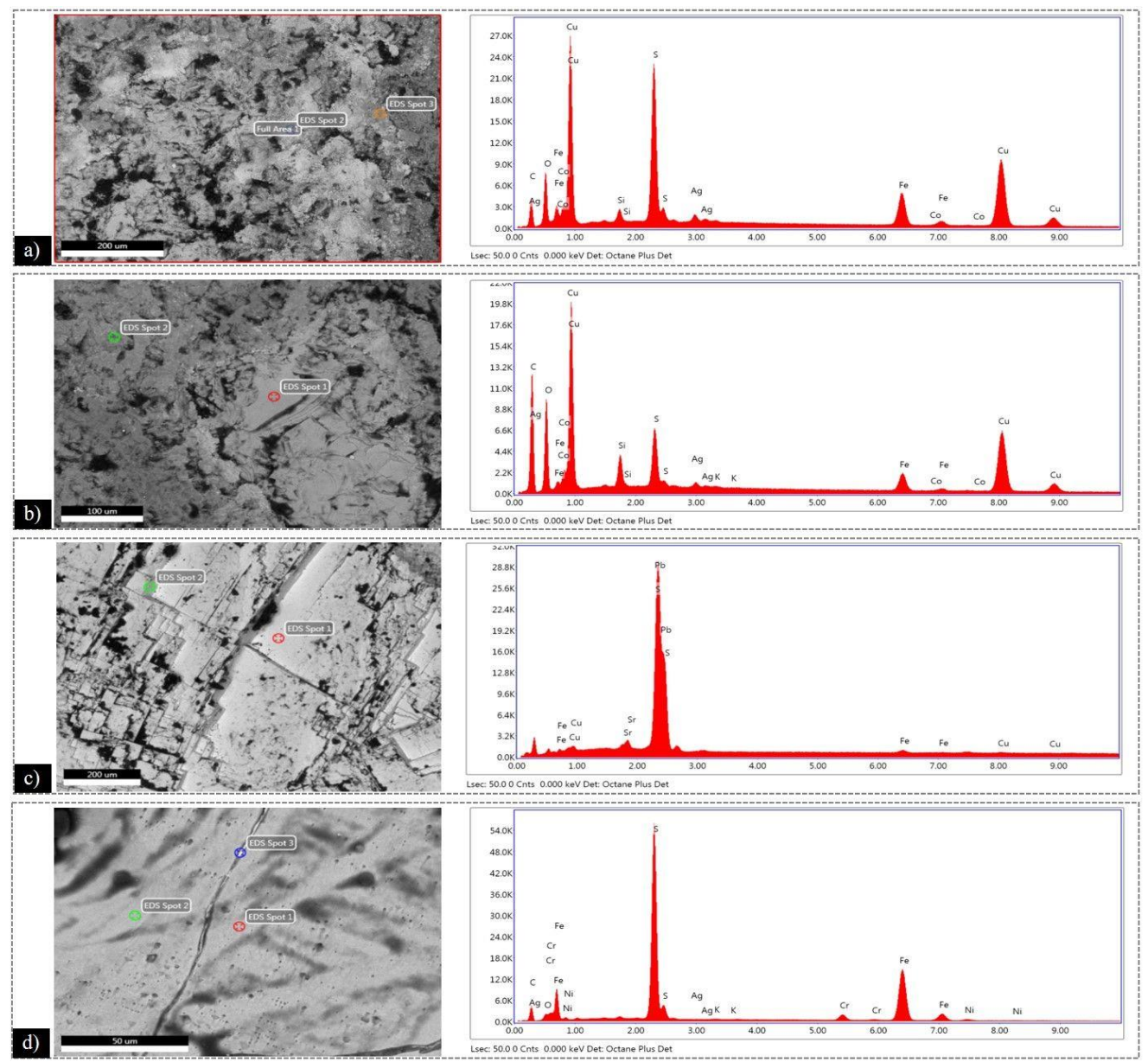

Fig. 10. SEM images and energy dispersive spectroscopy (EDS) of the mineralization of study area: a) chalcopyrite; b) chalcocite; c) galena and d) pyrite

\section{Discussion}

\subsection{Paragenetic Sequence}

The distinction between the different paragenetic stages of polymetallic mineralization in the Agdim - Ait Elfersi sector is based on the nature and textures of the mineralogical assemblages of the different veins and on the mode of establishment observed. Three stages have been observed explaining the majority of textures and mineralogical assemblages of the polymetallic mineralization of the Agdim-Ait Elfersi sector (Fig. 11):

\section{- Stage 1}

It corresponds to the establishment of base metal paragenesis in veins and disseminations in the Precambrian basement, especially in the rhyolitic features. It is associated with white barite, gray barite and iron oxides paragenesis. The metallic phases are essentially characterized by pyrite and chalcopyrite.

\section{- Stage 2}

It is characterized by the deposition of most of the polymetallic $\mathrm{Cu}-\mathrm{Ag}-\mathrm{Pb}$ mineralization in the broadly oriented NE-SW and E-W structures, which affected the Precambrian basement and its Paleozoic cover. This episode is associated with the deposition of an essential quartz matrix, sometimes 
with pink barite and quartz sacharoide. The metallic phases are represented by chalcopyrite, chalcocite, galena, sphalerite, and pyrite.

\section{- Stage 3}

It is characterized by the supergene alteration phenomena that are responsible for the dissolution of primary minerals and the neoformation of alteration minerals, such as cerussite, covellite, digenite, malachite, azurite, and iron oxides.

\begin{tabular}{|lccc|}
\hline & $\begin{array}{c}\text { Stage I } \\
\text { Early mineralizing episode }\end{array}$ & $\begin{array}{c}\text { Stage II } \\
\text { Polymetallic mineralization episode }\end{array}$ & $\begin{array}{c}\text { Stage III } \\
\text { Supergene episode }\end{array}$ \\
\hline White barite & & \\
Gray barite & \\
Gray barite & & \\
Gray barite & & \\
Pyrite & & \\
Chalcopyrite & & \\
Chalcocite & & \\
Sphalerite & & \\
Galena & & \\
Pink barite & & \\
Quartz & & \\
Sacharoid quartz & & \\
Cerussite & \\
Covellite & \\
Digenite & \\
Malachite & \\
Azurite & \\
Iron oxide & \\
\hline
\end{tabular}

Fig. 11. Paragenetic sequence of the polymetallic mineralization of the study area

\subsection{Geochemistry Data}

A sampling campaign was carried out in the area studied. These samples, 34 in number, were taken at surface in mineralized structures across the study area. The elements targeted in this campaign are copper, lead, silver, gold, mercury, zinc and iron. The correlation between these elements, especially between $\mathrm{Ag}-\mathrm{Hg}, \mathrm{Cu}-\mathrm{Hg}, \mathrm{Cu}-\mathrm{Ag}, \mathrm{Ag}-\mathrm{Pb}, \mathrm{Au}-\mathrm{As}$ and $\mathrm{Au}-\mathrm{Pb}$, shows a strong positive correlation with a correlation coefficient (R2) which varies between 0.1704 and 0.8038 . These correlations reflect the mineralogical associations between these elements, particularly between $\mathrm{Ag}-\mathrm{Hg}, \mathrm{Cu}-\mathrm{Hg}$ and $\mathrm{Cu}-\mathrm{Ag}$.

Geochemical analyzes of samples taken from mineralized structures in the Agdim - Ait Elfersi sector showed firstly the polymetallic character of this mineralization and then the existence of clear geochemical bonds and associations between the targeted elements. The high contents of $\mathrm{Ag}, \mathrm{Cu}$ and $\mathrm{Hg}$ are comparable with those which characterize epithermal-type deposits in the world (White and Hedenquist, 1990; Taylor 1995; Hedenquist et al., 2000; Sillitoe et al., 2003; Einaudi et al., 2003; Wang et al., 2019; Dilles and John 2020). Therefore, the high levels of silver and mercury in some samples analyzed probably indicate the existence of an $\mathrm{Ag}-\mathrm{Hg}$ epithermal system at the depth of this study area.

\subsection{Structural, Lithological and Hydrothermal Control}

The structural synthesis of the cinquefoil zones in polymetallic mineralization of the Agdim Ait Elfersi sector indicates the presence of a breaking break-out tectonics associated with a shear zone with the development of the C / S fabrics. This mineralization is relatively controlled by a conjugate fault system, probably operated during the Hercynian and/or Alpine orogeny. It corresponds to a complex system formed by an intersection between faults and strike-slip faults with E-W and NE-SW directions. Indeed, this shear zone is linked to two faults, one in the north with a dextral movement and the other with a sinister movement in the south. 
The E-W and NE-SW strike-slip faults played during the late Pan-African phase in the Neoproterozoic basement and during the Hercynian to tardi Hercynian phase in the Paleozoic cover (Dal Piaz et al., 2007; Malusà et al., 2007). Our study highlights their importance in the genesis and the establishment of polymetallic $\mathrm{Cu}-\mathrm{Ag}$-Pb mineralization at the level of the late Neoproterozoic-Lower Cambrian transition zone in the Agdim-Ait Elfersi sector. The Agdim-Ait Elfersi sector mineralization hosts in late Neoproterozoic rhyolitic features and in Lower Cambrian detrital features, Middle Cambrian paradoxidic shales play a tempering role. Rhyolites have undergone hydraulic pressure and intense hydrothermal alteration with the development of cataclasite structures. Detrital features underwent intense deformation and melonytization with the development of C / S structures.

Structural control will facilitate the circulation of hydrothermal fluids carrying mineralization (Awadh et al., 2008; Awadh and Nejbert, 2016). In addition to this structural control, there is lithological control (Awadh, 2019)., which translates into rheological control. In isotropic rocks, their permeability favors hydrothermal circulation (Awadh and Nejbert, 2016), on the other hand with impermeable anisotropic rocks, which do not facilitate the circulation of hydrothermal fluids. As a result, polymetallic $\mathrm{Cu}-\mathrm{Ag}-\mathrm{Pb}$ mineralization from the Agdim-Ait Elfersi sector occurs in rhyolitic and detrital features of the Late Neoproterozoic and Lower Cambrian, respectively.

\subsection{Mode of Genesis}

Based on field observations, the $\mathrm{Cu}-\mathrm{Ag}-\mathrm{Pb}$ polymetallic mineralization from the Agdim-Ait Elfersi sector marks out the transition zone between the terminal Neoproterozoic basement and its Lower Cambrian detrital cover. This transition zone is associated with the establishment of rhyolitic felsic volcanism generated by the late Neoproterozoic extensional tectonics, responsible for deposits of base and precious metal mineralization in the Anti-Atlas belt (Cheilletz et al., 2002; Levresse et al., 2004; Gasquet et al., 2005; Marcoux and Wadjinny 2005; Tuduri et al., 2006; Pelleter et al., 2007; Bouabdellah and Slack 2016; Levresse et al., 2016, 2017; Pelleter et al., 2016; Tuduri et al., 2018). Areas of interest that contain mineralization are generally concentrated where there is a pink rhyolite. It should be taken into account that the greatest concentrations of hydraulic breccias and hydrothermal alterations were observed in these rhyolitic features, where these powerful structures of 10 to $30 \mathrm{~cm}$ on average are constituted by quartz, barite, iron oxides, malachite, pyrite and chalcopyrite.

Consequently, the rhyolitic features could then constitute the source and the convective motor of the hydrothermal circulations responsible for deposits and the genesis of polymetallic $\mathrm{Cu}-\mathrm{Ag}-\mathrm{Pb}$ mineralization of the Agdim-Ait Elfersi sector. This mineralization was remobilized and redeposited in NE-SW trending fault structures that affected the Paleozoic cover during the Hercynian orogeny, not to mention the effect of Alpine orogeny. The polymetallic $\mathrm{Cu}-\mathrm{Ag}-\mathrm{Pb}$ mineralization in this sector concerned by this present study is linked to two major events. A late Pan-African event (Levresse et al., 2004 ; Gasquet et al., 2005 ; Tuduri et al., 2006 ; Pelleter et al., 2007 ; Bouabdellah and Slack, 2016 ; Tuduri et al., 2018) linked to felsic volcanism, responsible for the establishment of mineralization at the level of the basement, and then a Hercynian and Alpine event (Wafik et al., 2017a) which manifests by the remobilization of metals in the deformation corridors corresponding to faults, veins and mainly NE-SW strike-slip fault, along the shear zones.

\subsection{Regional Comparison}

The $\mathrm{Cu}-\mathrm{Ag}-\mathrm{Pb}$ mineralization of the Agdim - Ait Elfersi sector, which is exceptionally rich in copper and lead, as well as the high silver and mercury contents, demonstrate that it is, as in Imiter and Zgounder deposit (Table. 1), an epithermal mineralization associated with a mega-event during the Ediacaran - Cambrian boundary. This sector has strong analogies with the silver deposits of Imiter (Orguir et al., 1994; Levresse et al., 2004; Tuduri et al., 2006; Levresse et al., 2016, 2017; Tuduri et al., 
2018) and Zgounder (Marcoux and Wadjinny 2005; Pelleter et al., 2016; EL Aouad et al., 2021), geologically (felsic volcanism), stratigraphic (Transition zone between Precambrian basement and Paleozoic cover), structural (EW, NE-SW, NW-SE fractures) and geochemical (High content of Ag and $\mathrm{Hg}$ ).The sectors of Agdim - Ait Elfersi, Imiter and Zgounder could be expressions of the same late Neoproterozoic epithermal event (Gasquet et al., 2005; Bouabdellah and Slack, 2016; Wafik et al., 2017b; Tuduri et al., 2018), which would extend into the Anti-Atlas domain, starting more and more in define what could be a silver-bearing metallogenic province.

Table. 1. Regional comparison of Agdim - Ail Elfersi sector, Imiter and Zgounder ore deposit

\begin{tabular}{|c|c|c|c|}
\hline & $\begin{array}{c}\text { Imiter Ore deposit (Levresse } \\
\text { et al., 2004; Tuduri et al., } \\
\text { 2006, 2018). } \\
\end{array}$ & $\begin{array}{c}\text { Zgounder ore deposit (Marcoux } \\
\text { and Wadjinny 2005; Pelleter et } \\
\text { al., 2016). }\end{array}$ & $\begin{array}{c}\text { Agdim -Ait Elfersi sector } \\
\text { (This study) }\end{array}$ \\
\hline Location & Saghro inlier, Anti Atlas & Siroua massif, Anti Atlas & Northeastern of Saghro. \\
\hline $\begin{array}{l}\text { Geodynamic } \\
\text { context }\end{array}$ & Pluto-volcanic arc context & Pluto-volcanic arc context & Pluto-volcanic arc context \\
\hline $\begin{array}{l}\text { Metallogenic } \\
\text { period }\end{array}$ & Late Neoproterozoic & Late Neoproterozoic & $\begin{array}{c}\text { Late Neoproterozoic and lower } \\
\text { Cambrien }\end{array}$ \\
\hline Hosted rocks & Neoproterozoic black shales & $\begin{array}{c}\text { Volcano-sedimentary series of } \\
\text { Neoproterozoic }\end{array}$ & $\begin{array}{l}\text { Ouarzazate group and Lower } \\
\text { Cambrian features. }\end{array}$ \\
\hline $\begin{array}{l}\text { Associated } \\
\text { volcanism }\end{array}$ & Felsic volcanic rocks (rhyolite) & Felsic volcanic rocks (rhyolite) & Felsic volcanic rocks (rhyolite) \\
\hline Tectonic structure & $\begin{array}{c}\text { Fracturing systems: } \\
\text { N-S; NE-SW; E-W; NW-SE }\end{array}$ & $\begin{array}{c}\text { Fracturing systems: } \\
\text { E-W; N-S; NE-SW; NW-SE }\end{array}$ & $\begin{array}{c}\text { Fracturing systems: } \\
\text { N-S; NE-SW; E-W; NW-SE }\end{array}$ \\
\hline $\begin{array}{l}\text { Morphology of } \\
\text { the deposit }\end{array}$ & Pockets, veins, stockwork & $\begin{array}{l}\text { Lenticular, disseminations, lenses, } \\
\text { veins. }\end{array}$ & $\begin{array}{c}\text { Disseminations, veins, pockets, } \\
\text { stockwork }\end{array}$ \\
\hline Texture & Breccias, mosaic, disseminated. & Breccias, disseminated. & $\begin{array}{c}\text { Breccias, mosaic, disseminated., } \\
\text { banded }\end{array}$ \\
\hline $\begin{array}{l}\text { Hydrothermal } \\
\text { alterations }\end{array}$ & $\begin{array}{l}\text { Propylitization, silicification, } \\
\text { kaolinization, carbonation. }\end{array}$ & $\begin{array}{l}\text { Chloritization, carbonation, } \\
\text { silicification. }\end{array}$ & $\begin{array}{l}\text { Sericitization, carbonation, } \\
\text { silicification, hematitization, } \\
\text { chloritization. }\end{array}$ \\
\hline Gangue minerals & Quartz, dolomite & Quartz, calcite, chlorite. & Quartz, barite, chlorite \\
\hline Metallic minerals & $\begin{array}{c}\text { Native Ag, Argentite, Galena, } \\
\text { Pyrite, Arsenopyrite, Silver } \\
\text { Sulfosalt. }\end{array}$ & $\begin{array}{c}\text { Native mercury silver, galena, } \\
\text { pyrite, Arsenopyrite, chalcopyrite, } \\
\text { sphalerite }\end{array}$ & $\begin{array}{c}\text { Chalcopyrite, chalcocite, pyrite, } \\
\text { galena, Sphalerite. }\end{array}$ \\
\hline Metals & $\mathrm{Ag}, \mathrm{Hg}, \mathrm{Cu}, \mathrm{As}, \mathrm{Au}, \mathrm{Pb}$ & $\mathrm{Ag}, \mathrm{Hg}, \mathrm{Pb}, \mathrm{Cu}, \mathrm{Au}$ & $\mathrm{Cu}, \mathrm{Ag}, \mathrm{Hg}, \mathrm{Pb}, \mathrm{As}, \mathrm{Au}, \mathrm{Zn}$ \\
\hline
\end{tabular}

\section{Conclusions}

The $\mathrm{Cu}-\mathrm{Ag}-\mathrm{Pb}$ mineralization deposit in the Agdim Ait Elfersi sector, hosted in the rhyolitic features of the terminal Neoproterozoic and the detrital formations of the Lower Cambrian, present similar characteristics to the mineralization of the transition zone between the late Neoproterozoic and the Lower Cambrian in the Anti-atlas belt. According to the geochemical study, we figured out that the mineralized system shows a close association between precious metals and base metals, confirming its polymetallic name. The metallic procession of economic interest is $\mathrm{Cu}-\mathrm{Ag}-\mathrm{Pb}$, metals to which $\mathrm{Zn}, \mathrm{Hg}$ and $\mathrm{Ba}$ are largely added. The high levels of silver and mercury in some of the samples analyzed probably indicate the existence of an Ag-Hg epithermal system at depth. The Agdim - Ait Elfersi sector has strong analogies with the Imiter and Zgounder silver deposits in terms of (i) geological context: felsic volcanism, (ii) stratigraphic context: boundary of the Precambrian basement and the Paleozoic cover, (iii) structural deformation: EW, NE-SW and NW-SE fractures, and (iv) geochemical characteristics: high content of $\mathrm{Ag}$ and $\mathrm{Hg}$.

This analogy could be expressions of the same late Neoproterozoic terminal epithermal event (Gasquet et al., 2005; Bouabdellah and Slack, 2016; Tuduri et al., 2018), which would extend into the Anti-Atlas domain, increasingly beginning to define what could be a silver-bearing metallogenic province. 
Based on the different results presented in this manuscript, the following conclusions can be extracted:

- The Agdim - Ait Elfersi sector presented a polymetallic mineralization with copper, silver and lead;

- The mineralization is hosted by rhyolitic features of late Neoproterozoic and by detrital features of lower Cambrian;

- The Agdim - Ait Elfersi mineralization is associated with the Neoproterozoic and Cambrian boundary;

- The mineralization is controlled by a breaking beark up tectonics associated with a conjugate fault system, probably operated during hercynian and alpine orogeny;

- The mineralization is linked to two majors' event, a late Neoproterozoic event associated to felsic volcanism, and then a hercynian and alpine even, which manifest by the remobilization of metals in the deformation corridors;

- The sector of Agdim - Ait Elfersi has strong analogies with the Imiter and Zgounder silver deposits.

\section{Acknowledgements}

The authors thank the Baraka Mining Company for their collaboration and help during the field survey as well as the Faculty of Science of Marrakesh for providing thin and polished sections. The authors are very grateful to the reviewers, Editor in Chief Prof. Dr. Salih M. Awadh, the Secretary of Journal Mr. Samir R. Hijab, and the Technical Editors for their great efforts and valuable comments.

\section{References}

Abati, J., Aghzer A. M., Gerdes A., and Ennih, N. 2010. Detrital zircon ages of Neoproterozoic Sequences of the Moroccan Anti-Atlas Belt. Precambrian Research, 181 (1), 115-28.

Álvaro, J. J., Benziane, F., Thomas, R., Walsh, G. J., and Yazidi, A. 2014. Neoproterozoic-Cambrian Stratigraphic framework of the Anti-Atlas and Ouzellagh Promontory (high Atlas), Morocco. Journal African Earth Science, 98: 19-33.

Awadh, S. M., Habib, H.R. and Al-Bassam, K.S., 2008. Upper Cretaceous carbonate hosted zinc-lead-barite deposits in Northern Thrust Zone, northern Iraq: petrography and geochemistry. Arabian Journal of Geosciences, 1(1), 75-85.

Awadh, S.M., and Nejbert, K., 2016. Polymetallic sulfide ores hosted in Late Permian carbonate at the Alanish locality, northern Iraq: petrography and mineral chemistry. Arabian Journal of Geosciences, 9(9), 1-15.

Awadh, S.M., 2019. Zinc-lead mineralization in northern and northeastern Iraq. Iraqi Bulletin of Geology and Mining, (8), 19-40.

Baidada, B., Ikenne, M., Barbey, P., Soulaimani, A., Cousens, B., Haissen, F., Ilmen, S., and Alansari, A. 2018. Shrimp U-Pb Zircon geochronology of the granitoids of the imiter inlier: Constraints on the Pan-African Events in the Saghro Massif, Anti-Atlas (Morocco). Journal African Earth Science, 150, 799-810.

Bouabdellah, M., and Slack, J. F. eds. 2016. Mineral Deposits of North Africa. Mineral Resource Reviews. Cham: Springer International Publication.

Bouougri, E. 2003. The Moroccan Anti-Atlas: The West African Craton Passive Margin with Limited Pan-African Activity. Implications for the Northern Limit of the Craton. Precambrian Research.

Boyer, C., Chikhaoui, M., Dupuy, C., and Leblanc, M. 1978. Le Volcanisme Calco-Alcalin Précambrien Terminal de l'Anti-Atlas (Maroc) et Ses Alterations: Interprétation Géodynamique.' Comptes Rendus Hebdomadaires Des Séances de l'Académie Des Sciences.

Boyer, C., and Leblanc, M. 1977. Les Appareils Émissifs de La Formation Volcanique Infracambrienne de Ouarzazate, Anti-Atlas (Maroc). Comp. R. Hebd. Séa. Acad. Sci. 285, 641-644.

Cheilletz, A., Levresse, G., Gasquet, D., Azizi-Samir, M., Zyadi, R., Archibald, D. A., and Farrar, E. 2002. The Giant Imiter Silver Deposit: Neoproterozoic Epithermal Mineralization in the Anti-Atlas, Morocco. Mineralium Deposita, 37 (8), 772-81.

Choubert, G. 1963. Histoire géologique du Précambrien de l’Anti-Atlas’. Not. Mém. Ser. Géo. Mar., 162. 
Dal Piaz, G. A. (Coord) Schiavo, Malusà, M., Taj Eddine K., Algouti, A., Benvenuti, M., Eddebbi, A. 2007. Carte Géologique du Maroc au 1/50.000, Feuille Taghazout.’ Not. Mém. Ser. Géo. Mar. № 519.

De Wall, H., Kober, B., Errami, E., Ennih, N., and Greiling, R.O. 2001. Age de Mise En Place et Contexte Géologique Des Granitoïdes de La Boutonnière d'Imiter (Saghro Oriental, Anti-Atlas, Maroc).' 2ème Colloque International. Marrakech, 3MA, Mag. Mét et Min Assoc, 10, P19.

Destombes, S., Hollard, H., and Willefert, S. 1985. Lower Palaeozoic Rocks of Morocco'. Lower Palaeozoic Rocks of Morocco. Journal Wiley, 91-336.

Diallo, M., Bouabdellah, M., Levresse, G., Yans, J., Castorina, F., Klügel, A., Maacha, L. 2021. Mineralogy, fluid inclusion, and CO-sr isotope geochemistry to unravel the evolution of the magmatic-hydrothermal system at the Igoudrane Silver-Rich Deposit (Imiter District, Eastern Anti-Atlas, Morocco). Minerals, 11(9), 997.

Dilles, J. H., and John, D. A. 2020. Porphyry and Epithermal Mineral Deposits. In Encyclopedia of Geology (Second Edition), edited by Alderton, D., and Elias, S.A. 2020. 847-66. Oxford: Academic Press. doi:10.

D’Lemos, R. S., Inglis, J. D., and Samson, S. D. 2006. A Newly Discovered Orogenic Event in Morocco: Neoproterozic Ages for Supposed Eburnean Basement of the Bou Azzer Inlier, Anti-Atlas Mountains, 147 (1), 65-78.

Du Dresnay, R., Hindermeyer, J., Emberger, A., Caia, J., Destombes, S., and Hollard, H. 1988. Carte Géologique du Maroc au 1: 200 000, Feuille Todgha-Maider. Not. Mém. Ser. Géo. Mar., Nº 243.

Einaudi, M. T., Hedenquist, J. W., and Inan, E. E. 2003. Sulfidation State of Fluids in Active and Extinct Hydrothermal Systems: Transitions from Porphyry to Epithermal Environments. Society Eco Geology, 285-313.

EL Aouad, N., Admou, H., Wafik, A., Ahmid, A., Kharis, A. A., Atif, Y., Daafi, Y. and Chaib, L. 2021. Geology, geochemistry, and geodynamic implications of Ediacaran Magmatic rocks of the Zgounder Inlier, Siroua Window, Anti-Atlas, Morocco. Arabian Journal of Geoscience, 14 (4), 314.

El Bahat, A., Ikenne, M., Brian Cousens, B., Söderlund, U., Ernst, R., Klausen, M. B., and Youbi, N. 2017. New constraints on the geochronology and Sm-Nd isotopic characteristics of Bas-Drâa Mafic Dykes, Anti-Atlas of Morocco. Journal African Earth Science, 127, 77-87.

Ennih, N., and Liégeois, J. P. 2008. The Boundaries of the West African Craton, with Special Reference to the Basement of the Moroccan Metacratonic Anti-Atlas Belt. Geological Society, London, Special Publications 297 (1). Geological Society of London, 1-17.

Errami, E., Linnemann, U., Hofmann, M., Gärtner, A., Zieger, J., Gärtner, J., Mende, K., El Kabouri, J., Gasquet, D., and Ennih, N. 2020. From Pan-African Transpression to Cadomian Transtension at the West African Margin: New U-Pb Zircon Ages from the Eastern Saghro Inlier (Anti-Atlas, Morocco). Geological Society, London, Special Publications, September, SP503-2020-2105.

Fabre, J. 2005. Géologie du Sahara occidental et central. Série/Reeks: Tervuren African Geosciences Collection.

Fekkak, A, Pouclet, A., and Benharref, M. 2003. The Middle Neoproterozoic Sidi Flah Group (Anti-Atlas, Morocco): Synrift Deposition in a Pan-African Continent/Ocean Transition Zone. Journal African Earth Science, 37 (1), 73-87.

Gasquet, D., Ennih, N., Liégeois, J. P., Soulaimani, A., and Michard., A. 2008. The Pan-African Belt'. In Continental Evolution: The Geology of Morocco: Structure, Stratigraphy, and Tectonics of the Africa-Atlantic-Mediterranean Triple Junction, edited by Michard, A., Saddiqi, O., Chalouan, A., and Frizon de Lamotte, D. 2008. 33-64. Lecture Notes in Earth Sciences. Berlin, Heidelberg: Springer.

Gasquet, D., Levresse, G., Cheilletz, A., Azizi-Samir, M. R., and Mouttaqi, A. 2005. Contribution to a Geodynamic Reconstruction of the Anti-Atlas (Morocco) during Pan-African Times with the Emphasis on Inversion Tectonics and Metallogenic Activity at the Precambrian-Cambrian Transition'. Precambrian Research, 140 (3-4), 157-82.

Hedenquist, J., Arribas, A., and Gonzalez-Urien, E. 2000. Exploration for epithermal gold deposits. Reviews in Economic Geology, 13, 245-77.

Hefferan, K., Soulaimani, A., Samson, S. D., Admou, H., Inglis, J., Saquaque, A., Chaib, L., and Heywood, N. 2014. A Reconsideration of Pan African Orogenic Cycle in the Anti-Atlas Mountains, Morocco. Journal African Earth Science, 98, 34-46.

Hindermeyer, J. 1953. Le Précambrien-III du Sarho’. Comp. R. Hebd. Séa. Academic Science, 237 (17). 
Hindermeyer, J., Choubert, G., Destones, S., and Gauthier, H. 1974. Carte Géologique de 1'Anti-Atlas Oriental (Feuille de Dadès Jbel Sarhro) Au 1/200 000. Not. Mém. Ser. Géo. Mar., 161 (1977).

Hollard, H., Choubert, G., Bronner, G., Marchand, J., and Sougy, J. 1985. Carte Géologique du Maroc, Scale 1: 1, Not. Mém. Ser. Géo. Mar. 260 (2).

Ikenne, M., Söderlund, U., Ernst, R. E., Pin, C., Youbi, N., El Aouli, E. H., and Ahmid H. 2017. A c. 1710 Ma mafic sill emplaced into a quartzite and calcareous series from Ighrem, Anti-Atlas-Morocco: Evidence that the taghdout passive margin sedimentary group is nearly 1 ga older than previously thought. Journal African Earth Science. 127, 62-76.

Karaoui, B., Breitkreuz, C., Mahmoudi, A., Youbi, N., Hofmann, M., Gärtner, A., and Linnemann, U. 2015. U-Pb Zircon Ages from Volcanic and Sedimentary Rocks of the Ediacaran Bas Draâ Inlier (Anti-Atlas Morocco): Chronostratigraphic and Provenance Implications. Precambrian Research, 263, 43-58.

Landing, E., Geyer, G., and Heldmaier, W. 2006. Distinguishing eustatic and epeirogeny controls on Lower-Middle Cambrian Boundary Successions in West Gondwana (Morocco and Iberia). Sedimentology 53 (4), 899-918.

Latham, A., and Riding, R. 1990. Fossil evidence for the location of the Precambrian/Cambrian Boundary in Morocco. Nature Publishing Group, 752-54.

Leblanc, M., and Lancelot, J. R. 1980. Interprétation géodynamique du domaine pan-africain (Précambrien terminal) de l'Anti-Atlas (Maroc) à partir de données géologiques et géochronologiques. Canadian Journal of Earth Sciences. NRC Research Press Ottawa, Canada.

Letsch, D., Large, S. J. E., Bernasconi, S. M., Klug, C., Blattmann, T. M., Winkler, W., and Quadt, A. V. 2019. Northwest Africa's Ediacaran to Early Cambrian Fossil Record, Its Oldest Metazoans and Age Constraints for the Basal Taroudant Group (Morocco). Precambrian Research 320, 438-53.

Levresse, G., Cheilletz, A., Gasquet, D., Reisberg, L., Deloule, E., Marty, B., and Kyser, K. 2004. Osmium, sulphur, and helium isotopic results from the giant Neoproterozoic Epithermal imiter silver deposit, Morocco: Evidence for a mantle source. Chemical Geology, 207 (1), 59-79.

Levresse, G., Bouabdellah, M., Cheilletz, A., Gasquet, D., Maacha, L., Tritlla, J., Banks, D., and Azizi Samir M. R. 2016. Degassing as the main ore-forming process at the Giant Imiter Ag-Hg Vein deposit in the Anti-Atlas Mountains, Morocco. In Mineral Deposits of North Africa, edited by Bouabdellah, M., and Slack, J. F. 85-106. Mineral Resource Reviews. Cham: Springer International Publication.

Levresse, G., Bouabdellah, M., Gasquet, D., and Cheilletz, A. 2017. Basinal brines at the origin of the imiter Ag-Hg Deposit (Anti-Atlas, Morocco): Evidence from LA-ICP-MS Data on fluid inclusions, halogen signatures, and stable isotopes (H, C, O). A Discussion. Economic Geology, 112 (5). Geo Science World, 1269-72.

Liégeois, J.-P., Benhallou, A., Azzouni-Sekkal, A., Yahiaoui, R., and Bonin, B. 2005. The hoggar swell and volcanism: reactivation of the Precambrian Tuareg shield during Alpine Convergence and West African Cenozoic Volcanism. Special Paper of the Geological Society of America, 388, 379-400.

Liégeois, J-P., Fekkak, A., Bruguier, O., Errami, E., and Ennih, N. 2006. The Lower Ediacaran (630-610 Ma) Saghro Group: An Orogenic Transpressive Basin Development during the Early Metacratonic Evolution of the Anti-Atlas (Morocco). In: IGCP485 4th Meeting, Algiers. 2006. 57 pp.

Maloof, A. C., Schrag, D. P., Crowley, J. L., and Bowring, S. A. 2005. An expanded record of Early Cambrian carbon cycling from the Anti-Atlas Margin, Morocco. Canadian Journal of Earth Sciences, 42 (12), 2195-2216.

Malusà, M., Schiavo, A. (Coord), Taj Eddine, K., Algouti, A., Benvenuti, M., Dal Piaz, G., Eddebbi, A., 2007. Notice Explicative. Carte Géologique du Maroc au 1/50.000, Feuille Taghazout. Notes et Mémoires de Service Géologique de Maroc. 519.

Marcoux, É., and Wadjinny, A. 2005. 'Le gisement AgHg de Zgounder (Jebel Siroua, Anti-Atlas, Maroc) : un épithermal néoprotérozoïque de type Imiter. Comptes Rendus Geoscience, 337 (16), 1439-46.

Mouttaqi, A., Rjimati, E. C., Maacha, L., Michard, A., Soulaimani, A., and Ibouh, H. 2011. Les Principales Mines du Maroc'. Not. Mém. Ser. Géo. Mar., 9 (564).

Orguir, H., Macaudiere, J., Dagallier, G., Qadrouci, A., and Leistel, J. -M. 1994. Cadre structural du gite Ag-Hg d'Imiter (Anti Atlas, Maroc); Implication Metallogenique (Structural Framework of the Ag-Hg Deposit of 
Imiter (Anti-Atlas, Morocco); Metallogenic Inferences), Bulletin - Societe Geologique de France, 165(3), 277.

Ouguir, H., Macaudiere, J., and Dagallier, G. 1996. Le protérozoïque supérieur d'imiter, Saghro oriental, Maroc, un contexte géodynamique d'arrière-arc. Journal Africain Earth Science, 22 (2), 173-89.

Pelleter, E., Cheilletz, A., Gasquet, D., Mouttaqi, A., Annich, M., Camus, Q., Deloule, E., Ouazzani, L., Bounajma, H., and Ouchtouban, L. 2016. U/Pb ages of magmatism in the zgounder epithermal Ag- $\mathrm{Hg}$ deposit, Sirwa Window, Anti-Atlas, Morocco. In Mineral Deposits of North Africa, edited by Bouabdellah, M., and Slack, J., Mineral Resource Reviews, 143-165.

Pelleter, E., Cheilletz, A., Gasquet, D., Mouttaqi, A., Annich, M., El Hakour, A., Deloule, E., and Féraud, G. 2007. Hydrothermal zircons: A tool for ion microprobe U-Pb dating of gold mineralization (Tamlalt-Menhouhou Gold Deposit - Morocco), Chemical Geology, 245 (3), 135-61.

Sdzuy, K. 1978. The Precambrian-Cambrian boundary beds in Morocco (Preliminary Report). Geological Magazine, Cambridge University Press, 115 (2), 83-94.

Sillitoe, R., Jeffrey H., and Hedenquist, W. 2003. Linkages between volcano tectonic setting, ore-fluid compositions and epithermal precious metal deposits. Society Economic Geology, 315-43.

Soulaimani, A., Ouanaimi, H., Saddiqi, O., Baidder, L., and Michard, A. 2018. The Anti-Atlas Pan-African Belt (Morocco): Overview and pending questions. Comptes Rendus Geoscience, 350 (6), 279-88.

Taylor, B. E., 2007. Epithermal gold deposits. mineral deposits of Canada: A synthesis of major deposit-types, district metallogeny, the evolution of geological provinces, and exploration methods. Geological Association of Canada, Mineral Deposits Division, Special Publication, 5.

Thomas, R. J, Chevallier, L. P., Gresse, P. G, Harmer, R. E, Eglington, B. M., Armstrong, R. A., De Beer, C. H. 2002. Precambrian evolution of the Sirwa Window, Anti-Atlas Orogen, Morocco. Precambrian Research 118 (1), 1-57.

Thomas, R. J., Fekkak, A., Ennih, N., Errami, E., Loughlin, S.C., Gresse, P.G., Chevallier, L.P., and Liégeois, J.-P. 2004. A new lithostratigraphic framework for the Anti-Atlas Orogen, Morocco. Journal African Earth. Science, 39 (3-5), 217-26.

Tucker, M. E. 1986. Carbon isotope excursions in Precambrian/Cambrian Boundary Beds, Morocco. Nature 319 (6048). Nature Publishing Group, 48-50.

Tuduri, J., Chauvet, A., Barbanson, L., Bourdier, J.L., Labriki, M., Ennaciri, A., Badra, L. 2018. The Jbel Saghro $\mathrm{Au}(-\mathrm{Ag}, \mathrm{Cu})$ and $\mathrm{Ag}-\mathrm{Hg}$ metallogenetic province: product of a long-lived ediacaran tectono-magmatic evolution in the Moroccan Anti-Atlas. Minerals 8 (12), 592.

Tuduri, J., Chauvet, A., Ennaciri, A., and Barbanson, L. 2006. Modèle de formation du gisement d'argent d'Imiter (Anti-Atlas oriental, Maroc). Nouveaux apports de l'analyse structurale et minéralogique'. Comptes Rendus Geoscience, 338 (4), 253-61.

Wafik, A. Fettah, H. Rakhiss, L. Ouadjou, A. 2017a. Rich Merzoug and Afilou N'Khou Veins of the Oumjrane Deposit (Example of Oriental Anti-Atlas Copper Mineralization). European Scientific Journal. Vol.13, No.18 ISSN: 1857 - 7881 (Print) e - ISSN 1857- 7431. pp 251-271.

Wafik, A., Ramdani, A., El Aouad, N. El Ghazali, M. 2017b. A new interpretation of geodynamic context and typology of Moroccan Anti-Atlas silver deposits. European Scientific Journal.13 (12), 1857- 7881.

Walsh, G. J., Benziane, F., Aleinikoff, J. N., Harrison, R.W, Yazidi, A., Burton, W. C., Quick, J. E., and Saadane, A. 2012. Neoproterozoic tectonic evolution of the Jebel Saghro and Bou Azzer-El Graara Inliers, Eastern and Central Anti-Atlas, Morocco. Precambrian Research, 216-219, 23-62.

Wang, L., Qin, K-Z., Song, G-X., and Li, G-M. 2019. A Review of intermediate sulfidation epithermal deposits and subclassification. Ore Geology Reviews, 107 (4), 434-56.

White, N. C., and Hedenquist, J. W. 1990. Epithermal environments and styles of mineralization: Variations and their causes, and guidelines for exploration. Journal of Geochemical Exploration, 36 (1), 445-74.

Yajioui, Z., Karaoui, B., Chew, D., Breitkreuz, C., and Mahmoudi, A. 2020. U-pb zircon geochronology of the ediacaran volcano-sedimentary succession of the NE Saghro Inlier: Chronostratigraphic correlation on the northwestern margin of Gondwana. Gondwana Research, 87, 263-77.

Youbi, N., Kouyaté, D., Söderlund, U., Ernst, R.E., Soulaimani, A., Ahmid H., Ikenne, M. 2013. The 1750Ma magmatic event of the West African Craton (Anti-Atlas, Morocco). Precambrian Research, 236 (10), 106-23. 